\title{
Hugh Downman, MD (1740-1809) of Exeter and his poem on infant care
}

\section{P M Dunn}

Arch Dis Child Fetal Neonatal Ed 2003;88:F253-F254

Hugh Downman is best remembered for his poem on the care of infants in which he stressed the importance of breast feeding and proper examination.

$\mathrm{H}$ ugh Downman, physician and poet, was born in 1740 at Newton House, Exeter. He was educated first at Exeter Grammar School and then, in 1758, at Balliol College, Oxford where he graduated BA in 1763. Later the same year he was ordained in Exeter Cathedral. His clerical prospects being small, he then went to Edinburgh to study medicine. There he shared lodgings with the blind poet, Thomas Blacklock. 1769 found him walking the hospital wards in London and the following year proceeding to the degree of MA at Jesus College, Cambridge. He then practised medicine in Exeter, married the daughter of a colleague, Dr Andrew, and gained the reputation as an able, humane doctor and a most amiable man. However, chronic ill health caused him to retire from practice in 1778. But 12 years later he resumed active duties until ill health again forced retirement in 1805. He died on 23 September 1809 at the age of $69 .^{1-3}$

Downman (fig 1) was perhaps best known during his life as a man of letters. Besides many poems, he published a number of plays, helped to translate an edition of Voltaire's works, and founded a literary society with 12 members in Exeter in 1796. His best known poem, and the one relevant to perinatal medicine, was published between 1774 and 1776 with the title Infancy or the management of children: a poem in three books. Seven editions were published during his lifetime; the last in 1809 had the subtitle $A$ didactic poem in six books. The extracts that follow are taken from the $1776^{4}$ and $1803^{5}$ editions. Downman emphasised that "health is the greatest blessing man receives from bounteous Heaven" and that on "the management of these first years depends the future man".

Each of Downman's books is preceded by a summary of contents such as this from Book 1 :

\section{ARGUMENT}

Correspondence to: Professor Dunn Department of Child Health, University of Bristol, Southmead Hospital, Southmead, Bristol BSIO 5BN, UK p.m.dunn@bristol.ac.uk

Accepted

9 February 2003

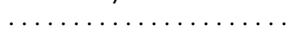

The Invocation and Introduction. Health is the greatest blessing of mankind. - It should be the chief aim of parents to procure their children the enjoyment of it. - Nature and instinct therefore are to be followed.Pernicious custom of giving children some drug soon after they are born. - The best remedy, at that time, is the first milk of the
mother.-Various reasons and motives for the mother's suckling her children.-An amiable duty.-Apostrophe to tender affection.-Directions how to choose a nurse, if the mother can not perform that office herself. - Cities destructive to infants. Recommendation of the country. - The mother should oversee the conduct of the nurse.-The nurse's usual manner of life should be altered as little as possible.Address to Habit.

Downman had little faith in the untrained and ignorant "wise women" of his day:

\section{On midwives and nurses}

"We write to reason: Hence ye doting train Of midwives and of nurses ignorant! Old beldames grey, in error positive And stiff in prejudice, whose fatal care Of death attends, or a life worse than death."

He continued: "the child is born. See, where the treacherous nurse ... prepares the poisonous drench: forwarn'd beware: within the fatal drug lurks death ..." "Nature will preserve whate'er

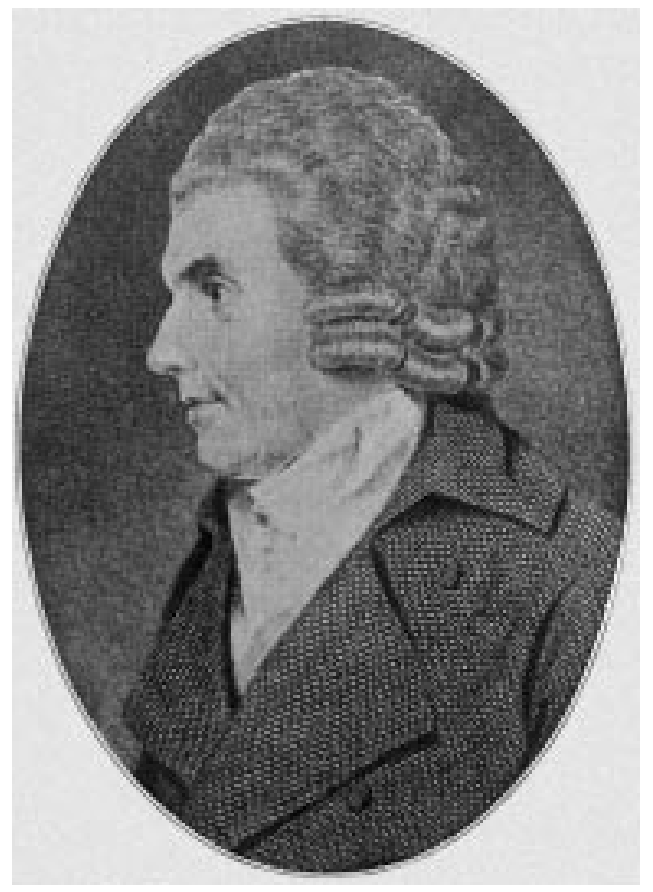

Figure 1 Hugh Downman, 1740-1809. 
she frames: is physic needful then? . . . The mother's breast without a moments pause ... is Nature's chymic mixture ... gently detersive, purifying, bland ... Hence too the mother is secure: the streams of health giving to her infant flow ..."

Nor did Downman accept that it was not possible to diagnose an infant's problems:

\section{On clinical observation}

"Because the child, with reason unendow'd

And power of speech, by words to express his grief

Nature permits not; some believe the source

Of anguish and affections is conceal'd

From every eye, and deem assistance vain.

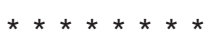

Yet nature, in thy child, tho' not in words, Speaks plain to those who in her language vers'd Justly interpret. Are the different tones Of woe unfaithful sounds? Can he, whose sight Hath traced the various muscles in their course, When irritated in the different limbs, Retracted, or extended, or supine,

Fix no conclusions on the seat of pain?

Is it of no avail to mark the breath, How drawn? the face? the motions of the eye? The salient pulse? the eruptions on the skin?

The skin itself, constructed or relaxed?

The mode of sleep? of waking? heat? or thirst?

From which, and numerous traits beside arranged,

Combined, abstracted, and maturely sigh'd,

Judgment its practice forms?"

Although Downman made no new and original contributions himself, he emphasised a number of important and at that time neglected aspects of infant care, especially the importance of breast feeding, extolling the charming and maternal bonding aspects. He considered that breast milk should be the only form of nourishment for the first two months but that from then on infants should be accustomed to small amounts of other foods, not solids till they have cut their teeth, but fresh broths, milk with bread or rice. The fittest time for weaning he considered was when the infant was about nine months old. It should be gradual.

\section{On weaning}

"The child long time

fed by this vital fluid, now requires

Dismission from the breast. Yet not at once,

As some have taught erroneous; such our frame

That every rash and sudden move may prove

The source of harm. More wise and cautious thou
Break through the tye of habit by degrees; And e'er the stream maternal be refused, His taste to different nutriment incline."

Downman also clearly appreciated the value of lactation and breast feeding in reducing frequent pregnancies with their ill effects.

\section{On the contraceptive influence of breast feeding}

"She who refused to her young one's lip, Her swelling bosum, each returning year Conceives, and each returning year sustains The pangs of child-birth. Harrass'd by fatigue The strongest constitution fails, but soon The weaker system, like a blighted flower, Falls underneath the shock. The nuring time Was meanst by wisest Nature, as a stay, A vacent interspace, in which the nerves, And threads of life unstrung, might re-assume The native tone, endured again with strength And corresponding vigour, to support

The day of toil ..."

Downman encouraged fathers to take an interest in their babies and in nursery matters. He praised George Armstrong as the pioneer of prophylactic medicine and, like William Buchan $^{6}$, supported the (pre-Jenner) use of smallpox inoculation, a practice that had been introduced by Lady Mary Wortley Montague (1689-1762) from Turkey in 1718:

\section{On smallpox inoculation}

"The triumph was reserved for female hand, ... Thine was the deed, accomplish'd Montague;

What physic ne'er conjectured, what described

By Pylarini, by Timoni sketch'd, Seemed to philosophy an idle tale A curious only; She by patriot love Inspired, and England rising to her view, Proved as a truth and proved it on her son."

\section{REFERENCES}

1 Ruhräh J. Hugh Downman. In: Pediatrics of the past. New York: Paul B Hoeber, Inc, 1925:514-18.

2 Still GF. Hugh Downman. In: The history of paediatrics. Oxford: Oxford University Press, 1931:468-70.

3 Ruhräh J. Hugh Downman, 1740-1809. American Journal of Diseases in Children 1932;43:1215-19.

4 Downman H. Infancy: a poem in three books. Edinburgh: John Bell, 1776.

5 Downman $\mathbf{H}$. Infancy or the management of children: a didactic poem in six books. 6th ed. Exeter: Treman and Son, 1803.

6 Dunn PM. Dr William Buchan (1729-1805) and his Domestic medicine. Arch Dis Child Fetal Neonatal Ed 2000:83:F71-3. 